\title{
La música y la danza en el antiguo egipto
}

\author{
Pilar González SerRano */**
}

El presente trabajo es parte de otro más amplio expuesto en varias de las conferencias que di, en los dos pasados cursos académicos, en la Facultad de Geografía e Historia de la U.C.M., dentro del seminario de «Estudios del Próximo Oriente y Egiptología» que, durante tres años consecutivos, ha impartido el Área de Arqueología de dicha Facultad.

Así pues, son varias las veces que en estos dos últimos años he hablado sobre «música y danza en el Antiguo Egipto», en ocasiones de modo sistemático, conforme a un programa temático y cronológico, como fue en el caso del citado seminario en otras, de forma más concreta y puntual, como hice en la conferencia pronunciada en la UNED el 13 de enero de 1994, dentro del curso monográfico que bajo el título de "Guerra y Religión en el Próximo Oriente y Egipto», dirigió el Dr. García Moreno y coordinó la Dra. Vázquez Hoys, y al cual me cupo el honor de ser invitada a participar.

En dicha ocasión traté sobre la evolución de las orquestas en la antigua civilización egipcia en función de los cambios que se produjeron como consecuencia de la llegada a Egipto de princesas asiáticas con sus correspondientes séquitos, lo que accnteció, sobre todo, en el transcurso del llamado Imperio Nuevo. Tales cortejos, instalados en los harenes reales y casas principescas cambiaron en buena parte, como era de esperar, no sólo los hábitos sociales, sino también las celebraciones religiosas y cortesanas. Como material gráfico aporté toda una serie de ilustrativas imágenes, no sólo referentes a los muchos instrumentos musicales que hasta nosostros han llegado y que se conservan en los principales museos del

\footnotetext{
* Profesora Titular de Arqueología. Universidad Complutense de Madrid.

** Ciclo: Guerra y Religión en el Próximo Oriente y Egipto.
} 
mundo, sino también a las escenas representadas en las pinturas y relieves estucados de las tumbas reales y privadas, donde se encuentran las más detalladas crónicas de la vida y costumbres de los antiguos egipcios.

En esta ocasión, mi propósito no es otro que el hacer una breve síntesis de los muchos e interesantes aspectos que este tema presenta para ofrecer una visión general del mismo. Música y danza son unas de las manifestaciones más expresivas de la espiritualidad humana, y en ellas intervienen las facultades más complejas que regulan nuestra psicomotricidad. A lo largo de los siglos, tal vez desde el momento mismo en que el hombre fue hombre, es decir, desde que fue capaz de cantar, en vez de gritar, y de bailar, en vez de saltar, ambas han caminado tan estrechamente unidas que es imposible estudiarlas por separado.

En cada cultura, los signos de identidad más dinámicos y emotivos continuan siendo la música y el baile, hasta el punto de que actuan como activos resortes de solidaridad y tácito acuerdo entre individuos y colectivos humanos, no sólo en el plano político y social, sino principalmente en el religioso y patríotico, de suerte que unos compases o unos determinados pasos de danza pueden llegar a tener mayor poder de convocatoria que la más ardiente de las arengas, porque en ellos se concentran los rasgos esenciales de una larga tradición, o de una toma de postura concreta, en un determinado momento. A nivel individual, sabido es, asimismo, que los momentos más significativos de la vida de una persona suelen asociarse a la música que, en cada momento, les sirvió de marco, consciente o inconscientemente, hasta tal punto que al escuchar una determinada melodía se suscita la evocación de vivencias asociadas, «su edición en pantalla», que diríamos en términos actuales.

La música es el arte de la expresión anímica a través del ritmo y de los sonidos. Por danza se entiende el movimiento acompasado del cuerpo, marcado por los movimientos de los pies y manos, acompañado por el batir de palmas o por el canto. A su vez, el canto es la ejecución de una melodía vocal y monódica por medio de la laringe -el primero y principal de todos los instrumentos musicales-y las vibraciones de la voz. Las personas pueden hablar, gritar, lamentarse, pero sólo cantan cuando emiten sonidos armónicos y acompasados, por medio de los cuales pueden expresar, mejor que con la palabra, sus emociones, pesares, alegrías y duelos.

Desde tiempos prehistóricos el hombre manifestó sus estados de ánimo personales y colectivos por medio de danzas y ceremonias mágico-simpáticas en las que, a juzgar por los testimonios gráficos que se han conservado, no faltaron los adornos, máscaras e incluso disfraces de carácter ritual. Danzas guerreras, de propiciación para la caza y para la fecundidad 
debieron de ser las principales. En ellas el acompañanimiento rítmico sería el batir de palmas o en entrechocar de palos primero, de crótalos y tambores más tarde, y el musical, la entonación de salmodias o cánticos rituales interpretados en grupo o con la alternancia del «sólo», a cargo chamán o hechicero, y la del coro formado por los participantes al acto.

Lo más probable es, como bien se ha dicho, que los instrumentos idiófonos o de percusión precedieran en el tiempo a los membráfonos, aerófonos y cordófonos, ya que marcar el ritmo por medio del palmeo sigue siendo un acto instintivo desde la propia infancia. Junto a las escenas de danza que nos han llegado en las pinturas rupestres, se encuentran algunos instrumentos testimoniales, como es el caso de la flauta de Pair nonPair (Francia) fechable en el Gravetiense (Paleolítico Superior), en torno al 20.000 a.C. Con ella se documenta la presencia de instrumentos de viento desde fechas tan remotas. En cuanto a los de cuerda hay que decir que su desarrollo debió de correr de forma consecuente al empleo generalizado del arco en el Magdaleniense y en el Epipaleolítico. Es muy probable que la propia vibración de la cuerda tensa (fabricada con tendones de animales) sugiriera la idea de aumentar su número y sus condiciones vibratorias. De esta forma, y para tales fechas hay que suponer ya en uso los más primitivos instrumentos musicales pertenecientes a las grandes familias citadas. De todas estas cuestiones se ocupa, en la actualidad, la "Etnomusicología", una nueva e interesante ciencia encargada de estudiar el folklore de los pueblos primitivos actuales y de rastrear los «sonidos perdidos" de las viejas culturas que nos dejaron constancia de su música a través de los instrumentos que han llegado hasta nosotros, y de las imágenes en las que se ven ejemplos de su utilización, pero, por desgracia, sin la menor anotación sobre sus claves de ejecución.

El inicio de los estudios de Musicología egipcia se asocian a los de la propia Egiptología, es decir a la famosa expedición napoleónica al Valle del Nilo (1799) y a la no menos célebre de Champollion (1828-30), ya que en el transcurso de las mismas se adquirieron, entre múltiples y variadas piezas arqueológicas, un buen número de instrumentos musicales que fueron depositados en el Louvre. Posteriormente, hay que destacar la labor de Mariette quien fue quien realizó los primeros estudios sobre la evolución orquestal y sociológica de la antigua música de Egipto.

Fue el propio Mariette quien junto con Du Locle asesoró a Antonio Ghislanzoni, el autor del libreto de Aida, y al propio Verdi, quien compuso la música. Dicha ópera se escribió por encargo de Ismael Pachá, virrey de Egipto y fue estrenada en el Cairo la Nochebuena de 1871, con motivo de la inauguración del Canal de Suez, construido por el ingeniero y diplomático 
Fernando María de Lesseps (1805-1894). Como era de esperar, Verdi hizo una versión romántica de la corte faraónica, consciente de que nada tenía que ver con la realidad histórica. Es más, como músico genial, en el que el talento y el oficio fueron siempre a la par, tuvo muy presente lo difícil y absurdo que podía resultar el intentar parodiar un pasado aún mal conocido. Lo que si hizo fue utilizar con gran profusión los elementos de viento y cuerda, con tal sonoridad y acierto que a partir del estreno de tan célebre ópera, el gran público, sigue asociando la música egipcia, en un acto de fe, con la compuesta por Verdi para la citada obra.

De la sutil perspicacia de Verdi son testimonio sus propias reflexiones, expresas en una carta al conde de Arrivebene, en la que criticaba las tentativas hechas por un tal Fetis, autor de una Historia de la Música, para llegar a tocar un instrumento de viento egipcio: "No crea que aborrezco a ese charlatán porque me ha estado cansando, sino porque un día me metió de cabeza en el Museo de Florencia para inspeccionar un tubo en el cual pretende haber descubierto el sistema de la antigua música egipcia, como asegura en su Historia de la Música ¡Qué bribón! Así se falsea la historia y los tontos aumentan sin que se desmienta el engaño".

Desde el siglo pasado hasta el momento actual no han faltado serios estudios sobre la música y la danza en el antiguo Egipto, algunos de los cuales figuran en la bibliografía básica que aparece al final de este trabajo, pero el caso es que, como entendió Verdi, por más que nos acerquemos a su realidad, sus sonidos seguirán siendo «sonidos perdidos», susceptibles tan sólo de ser evocados con las claves de la intuición y la fantasía.

En El Egipto antiguo, las raíces más profundas de su música y danzas hay que buscarlas en el desarrollo de dos actividades fundamentales para su economía y supervivencia: la agrícola, en la que las labores de cosecha y siembra reunían, desde las etapas iniciales del Neolítico, a grandes colectivos en una tarea común; y la de la caza, actividad que durante mucho tiempo conservó el carácter numinoso y elitista del que gozó en épocas paleolíticas y epipaleolíticas, reservándose su práctica a reyes y nobles, ya que en ella podían y debían demostrar su arrojo y buena forma física. Más tarde, serían las ceremonias funerario-religiosas en honor de Osiris otra de las grandes fuentes de inspiración musical, en este caso para acompañar a las celebraciones rituales relacionadas con el mundo de la muerte y de la resurreción, así como las consagradas al culto de Hathor, la vaca sagrada, recuerdo de la gran diosa madre prehistórica, convertida con el tiempo en divinidad nutricia, en la «sagrada nodriza del faraón». También llamada «señora del sicomoro,» fue venerada, asimismo, como protectora 
del amor y, en consecuencia, asociada, en la Baja Época, con la AstartéTanit púnica y la Afrodita griega.

La inundación anual de los campos y la posterior retirada de las aguas del Nilo, obligaban a los egipcios a sumar sus fuerzas en las labores de siembra y cosecha en los períodos previstos, y es muy probable que fuera en este ambiente donde, para acompañar a los llamados «cantos de siembra y siega", presentes en todas las culturas agrarias, surgieran los primeros instrumentos musicales, los más primitivos de cuantos se conocen: los palos o bastones de entrechoque. Con ellos se supone que, antes de ser utilizados para marcar los ritmos que acompañaban a los cantos entonados mientras se realizaban las faenas agrícolas, se usasen para ahuyentar a los pájaros o a los insectos de los sembrados. Dichos palos son muy semejantes a las actuales "claves» presentes en las orquestas cubanas, en las cuales aún siguen vibrando los acentos «afros» (fig. 1).

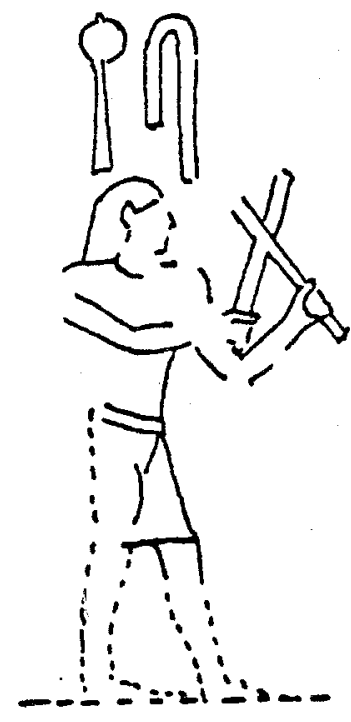

Figura 1. Tocador de «palillos de entrechoque». Tumba de Menturherkhepechef

El canto de siega se conocía con el nombre de «canto de Maneros», nombre de quien se tenía por el hijo único del primer rey de Egipto. Su leyenda era semejante a la del Lityerses frigio y el Bornos bitinio. Maneros se identificaba, en última instancia, con el propio Osiris y, por lo tanto, con el espíritu del grano ociso por la hoz del segador. De suerte, que en el 
tiempo de cosechas, el grito de ¡Manero!, que, a la vez significaba ¡vuelve a casa!, brotaba al unísono, ritmando el trabajo, de las gargantas de los campesinos que segaban las doradas espigas de los campos.

Los palos de entrechoque aparecen ya en las manos de figuritas de danzantes que adornan las paredes de los vasos de cerámica pintada ( $D$ Ware) del período de Nagada II, fechables hacia el 3200 a. C (fig. 2).

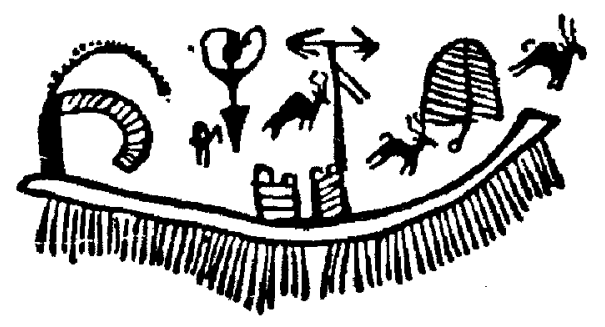

Figura 2. Tocadora de crótalos. Detalle de la decoración de una vasija de la cultura de Nagada /l (D-Ware), hacia 3200 a.C.

Posteriormente, se utilizaron en las danzas de crótalos o palillos que, a lo largo del tiempo, debieron de mantener su carácter ancestral y primitivo. Primero se fabricaron con cañas, con madera y hasta con tierra cocida. Más tarde, adquirieron diversas formas, convirtiéndose en instrumentos de percusión, marfil (colmillos de hipopótamo) o de hueso. Generalmente eran dobles, unidos entre sí por un cordel, y se tocaban por parejas con ambas manos. Los crótalos («mainit»), eran menos largos que los palillos. Finamente trabajados, se remataban con figuras zoomorfas e, incluso, antropomorfas. En otras ocasiones se tallaron en forma de manos, o de antebrazos rematados por manos de largos dedos. La cara de percusión, no decorada, presentaba, a veces, una acanaladura con el fin de poder obtener sonidos más timbrados (fig. 3).

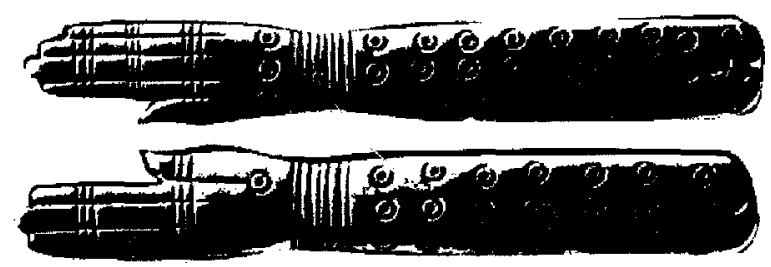

Figura 3 Crótalos en forma de antebrazo y manos. Dinastia III. Hueso $(17 \mathrm{~cm}$. de altura). Londres, Museo Británico. 
Los crótalos que han llegado hasta nosotros son muy numerosos y de formas muy variadas. Aparecen ya en las tumbas de época tinita y su presencia se mantiene, de modo ininterrumpida, hasta la Baja Época, generalizándose su uso en época griega y romana. Utilizados para los acompañamientos ritmícos no llegaron a desplazar, sin embargo, a los grupos de palmeros o de chasqueadores de dedos, que no suelen faltar, como necesarios jaleadores, en las escenas de música y danza, al igual que sucede, por poner un ejemplo, en los cantes y bailes de Andalucía. En cuanto a la «castañuela», cuyo nombre latino «castanea», hace referencia a su peculiar diseño, cabe decir que de origen probablemente fenicio, su uso se generalizó en época griega, tras experimentar una larga evolución en sus distintas modalidades, algunas de las cuales se pueden rastrear en el propio Egipto, concretamente en los crótalos rematados por cabezas antropomorfas o por simples cazoletas partidas (fig. 4).

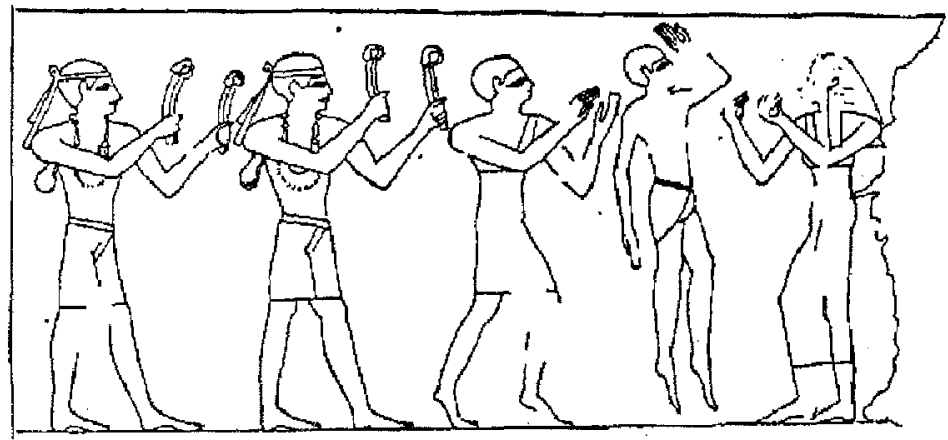

Figura 4. Danza hatórica con acompañamiento de crótalos rematados por cabezas antropomorfas, palmero y chasqueadora de dedos. Tumba de Amenemhat. Imperio Medio

Por otro lado, el boomerang, la peculiar arma arrojadiza de ida y vuelta (en el caso de no atinar en el blanco), utilizada tanto en la guerra como en la caza, se convirtió, asimismo, en un instrumento de entrechoque y percusión que llevaban en las manos los bailarines de la llamada, por esta razón, «danza del boomerang». En la paleta escutiforme de la «cacería del león", fragmentada en dos partes, repartidas entre el Museo Británico y el de El Louvre, los cazadores, además de arcos y flechas empuñan este tipo de armas (fig. 5). 


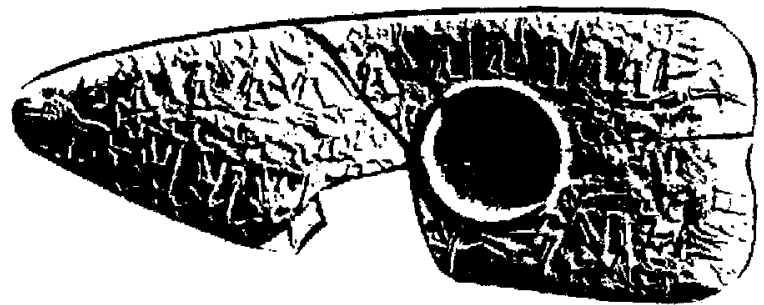

Figura 5. Paleta protodinástica procedente de Hierakómpolis, hacia 3100 a.C. París, Museo de El Louvre; Londres, Museo Británico

Más tarde, su uso será frecuente en manos de los nobles tebanos, quienes se hicieron representar en sus tumbas dedicados al noble deporte de abatir patos en los pantanos, y en la de los participantes en la ya citada danza (figs. 6 y 7 ).

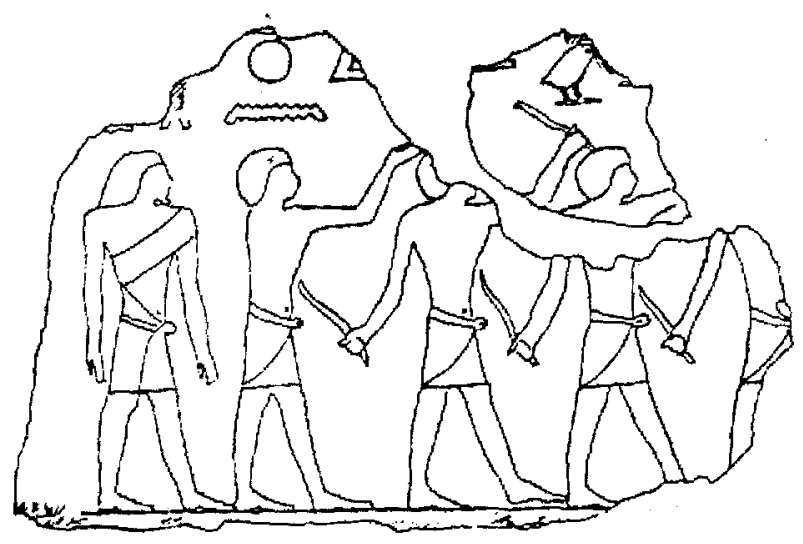

Figura 6. “Danza del boomerang». Relieve del templo sola de Niusire (2453-2422 a.C.)

De entre todos los instrumentos musicales de Egipto, quizás ninguno tan peculiar como el sistro. Difundido en el ámbito griego y latino, su nombre se hace derivar de los vocablos «seistron» (lo que se agita) y "sistrum», con los que se aludía a lo que, en sus órigenes fue el sonajero del 


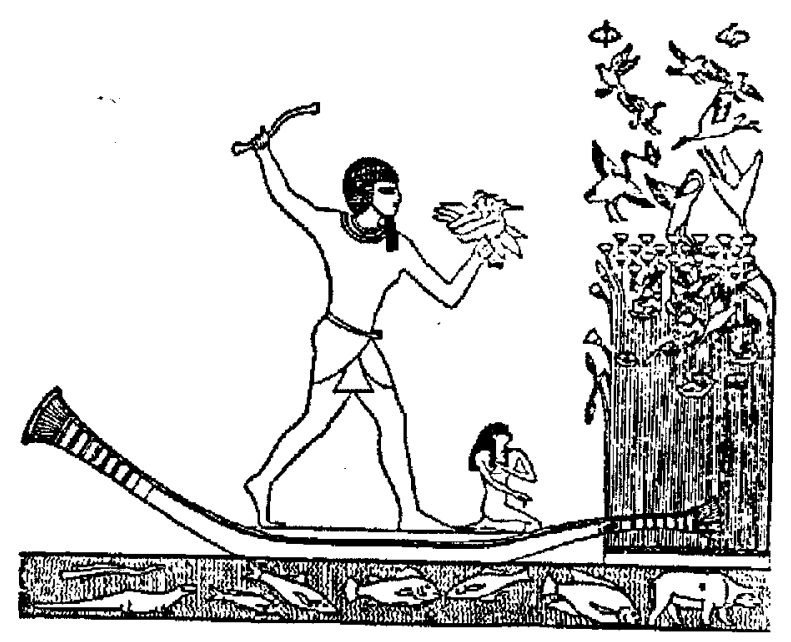

Figura 7. Cacería de patos salvajes con boomerang. Tumba de Nakht. Imperio Nuevo

«divino niño» (Horus, lhy, Harpócrates, etc.). Su nombre, en egipcio, «sehem» (fuerza), claramente onomatopéyico, aludía al ruido que hacía al ser agitado y con el cual se suponía que se ahuyentaban todos los maleficios que pudieran acechar el crecimiento del joven dios. Probablemente, en sus orígenes, debió de ser nada más que un haz de ramas de papiros que, al ser sacudidas por las madres ante los niños lactantes, producían un doble y beneficioso efecto: el de entretenerles y, a la vez, el de librarles de las picaduras de los insectos que, al igual que hoy sucede en tierras africanas, se ensañaban en sus tiernas carnes siendo la causa de innumerables y hasta mortales enfermedades.

La presencia de esta singular sonaja está documentada desde mediados del III milenio a.C., aparecierdo siempre asociada a las celebraciones religiosas de carácter hatórico, en los tiempos más antiguos, o isíaco, en los más recientes, ya que Isis asumiendo la esencia de la propia Hathor, acabó convirtiéndose no sólo en una " kourotrophos" (portadora del niño), sino también en una «mater lactans», coronada por el disco solar y los cuernos sagrados, además del trono, símbolo de su propio nombre, que fue su tocado original (figs. 8,9 y 10).

Como es sabido, su culto se extendió por toda la cuenca mediterránea y con él el uso del sistro en las procesiones celebradas en su honor. En ellas, la presencia de las «sistrata turba» era una de sus rasgos más característicos. 

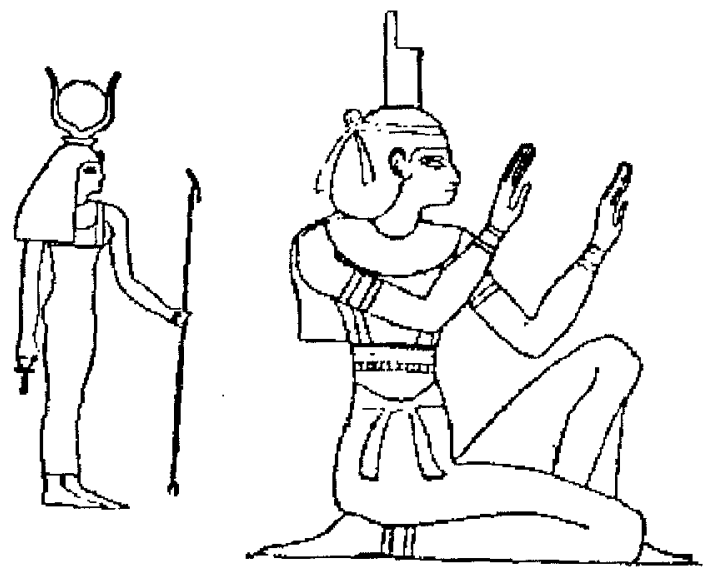

Figura $8 \quad$ La diosa Hathor
Figura 9. La diosa Isis. Lleva en la cabeza el signo gráfico de su nombre

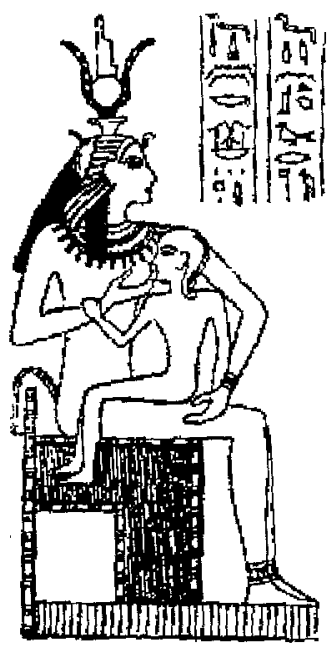

Figura 10. Isis "lactans", coronada con el tocado de Hathor y el suyo propio

Aunque la forma del sistro es inconfundible, ya que estaba formado por un mango y una lámina curva de metal (a veces de oro y de plata) arqueada y cerrada, atravesada por varillas metálicas provistas de sonajas, lo cierto es que varió sus modelos según la época y el contexto social en que fue utilizado. Así, mientras algunos, como los aparecidos en la tumba de Tutankamón hacen gala de una gran sencillez de diseño, otros son auténticas piezas de lujo. En general, se distinguen dos modalidades esenciales: el sistro simple ("sehem»), difundido con el culto a Isis por todos los países mediterráneos, como ya se ha dicho, y el naoforme o «naos sistrum» («sheseshet»), coronado por una especie de templete que, en ocasiones, cobijaba la cabeza de Hathor, razón por la cual también se les ha denominado "sistros hatóricos». Estos últimos sólo fueron utilizados en Egipto y, principalmente, en las ceremonias dedicadas a dicha divinidad. En ellas se usaba, asimismo, un instrumento muy semejante a la actual carraca (o matraca). Tanto el sistro, como la carraca, funcionaban ritualmente como ahuyentadores del mal. Al parecer, el primer portador del sistro fue el dios niño lhy, hijo de Hathor quien lo alumbró en el «mammisi» (sala del nacimiento) del templo de Dendera, localidad consagrada, desde antiguo, al culto de la diosa y al de su divino infante, tenido como patrón de la música y de los músicos. En la Baja Época se asoció con Harpocrátes o el Horus niño, hijo de Isis, que mordido por un escorpión fue 
curado milagrosamente por su madre, convirtiéndose, de esta forma, en el « dios del santo remedio» contra los animales venenosos. Asimismo, portador del sistro también fue Nefertum, el hijo de Ptah y de Sekhmet, con los que constituía la tríada menfita. Nefertum era venerado como la personificación del loto primigenio del cual respiraba Ra su perfume, y del cual había brotado el sol a la mañana del mundo (figs, 11, 12 y 13).

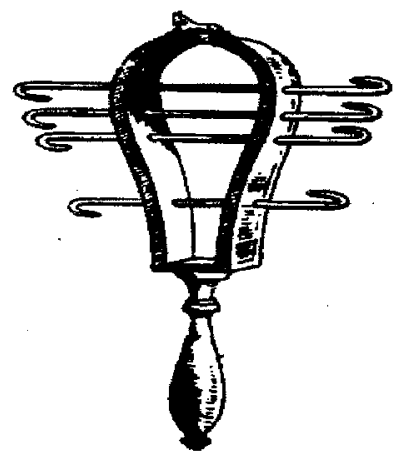

Figura 11. El sistro simple o «sehem»

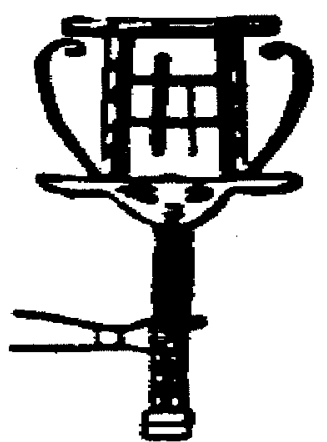

Figura 12. El sistro hatórico (o naoforme), llamado en egipcio "sheseshet»

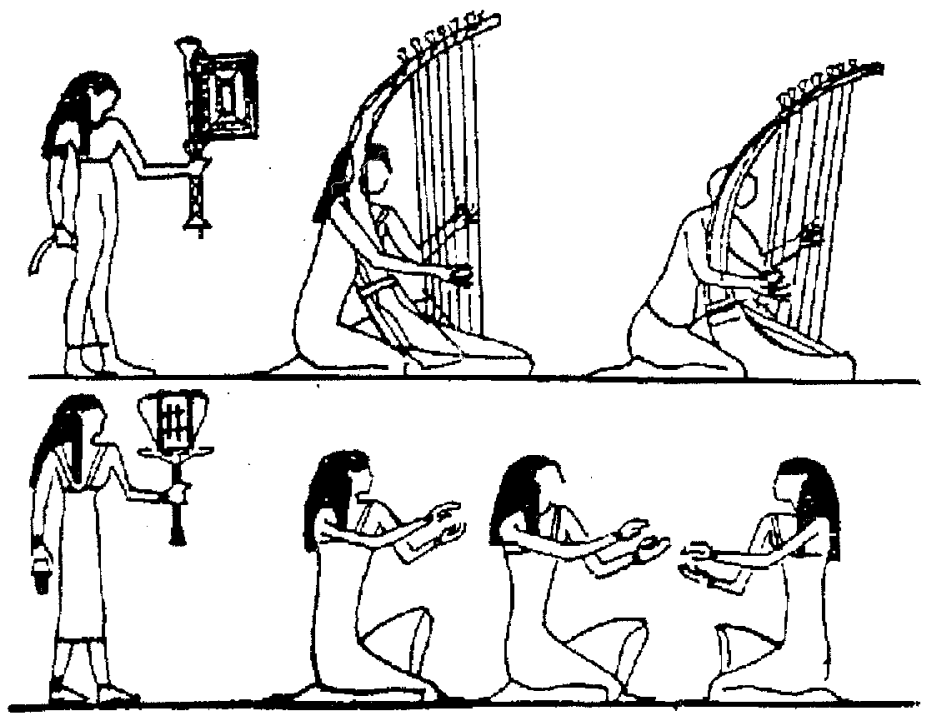

Figura 13. Orquesta femenina: arpistas, palmeras, tocadora de sistro y tocadora de carraca. Tumba de Ameni 
Los membráfonos o tambores («ser») no aparecen documentados en Egipto hasta el Imperio Medio, en torno al año 2000 a. C., excepción hecha del gran tambor representado en uno de los relieves del templo solar de Neusere, de la V dinastía (2453-2422 a. C), semejante a los de Sumer, tal vez porque, en sus orígenes, la música egipcia fue más melódica que rítmica. En realidad, el tambor fue, sobre todo, un instrumento militar, por lo que, en un principio, no solía aparecer en las escenas de música y danza. El ejemplar más antiguo de cuantos se conservan procede de Beni-Hassan, localidad que, como es sabido, alcanzó una gran prosperidad y cierta independencia en el Imperio Medio. Es de forma cilíndrica, de madera de palmera y con sus extremos cubiertos de piel bien tensada. El uso del tambor, se generalizó en tiempos de la dominación de los hicsos y, partir de entonces, aparece con frecuencia en todo tipo de actos y bajo formas muy variadas. Tenemos documentados tambores rectangulares, cónicos, bicónicos y en forma de «barrilete». Los circulares y con aro circundante, es decir los "tympana", se usaron, sobre todo a partir del Imperio Nuevo y por influencia asiática (fig. 14).

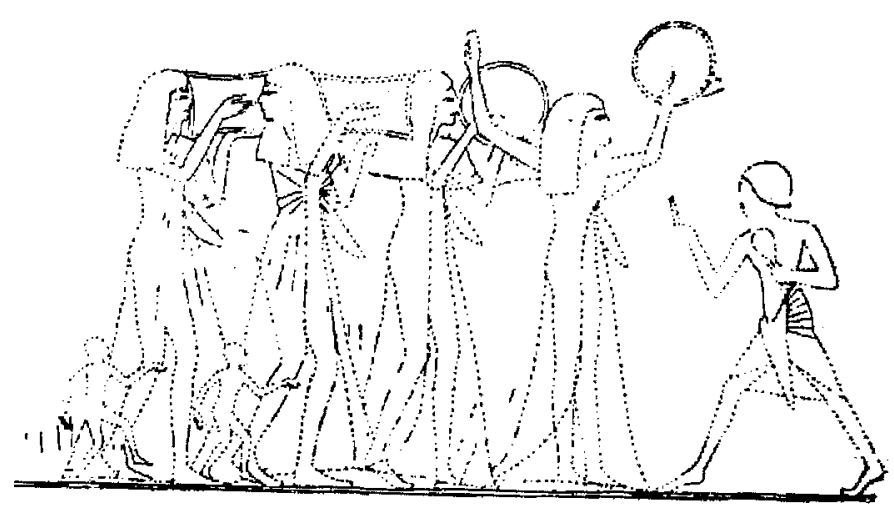

Figura 14. Tocadoras de tambores redondos y rectangulares. Tumba de Neferhotep. imperio Nuevo.

Entre los instrumentos aerófonos, el más antiguo de todos los conocidos fue la flauta oblicua o larga («ma.t»), documentada desde época predinástica, como puede apreciarse en la paleta de esquisto $(43 \mathrm{~cm}$. de alto) que, procedente de Hierakómpolis (Kom el-Ahmar) se conserva en el 
Ashmolean Museum de Oxford. En ella, junto animales de la estepa, y otros de aspecto fantástico, incluido un «protogrifo», aparece un personaje, cubierto con una máscara de cánido, tocando una flauta larga (fig. 15).

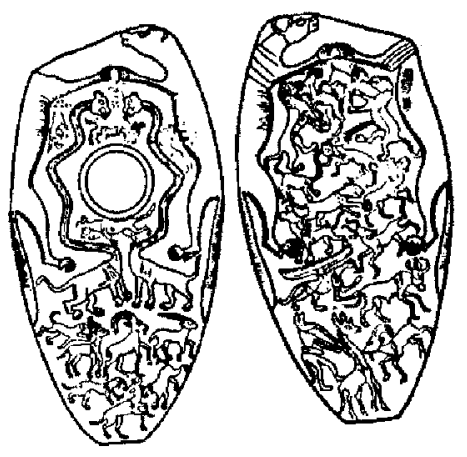

Figura 15. Paleta de afeites protodinástica de hacia el 3100 a.C. Esquisto $143 \mathrm{~cm}$. de altura). Oxford, Ashmolean Museum.

Este instrumento, medía unos $90 \mathrm{~cm}$. de longitud y tenía entre dos y seis orificios. El sonido se producía soplando por el extremo libre superior y las distintas notas, tapando, de forma adecuada los distintos huecos. Compartía el nombre de «ma.t» con el clarinete y el óboe, siendo la terminación «t» el indicador de su género femenino. En la actualidad, pervive en el mundo islámico, con el nombre persa «nay» y el árabe "qasaba». En las orquestas aparecía junto con el arpa, en el Imperio Antiguo y Medio, y con el arpa y el laúd, a partir del Imperio Nuevo (fig. 16).

El clarinete doble («ma'met») se documenta, al menos desde la V dinastía ( en torno al 2.400 a.C.). Se hacía con dos tubos de caña paralelos,

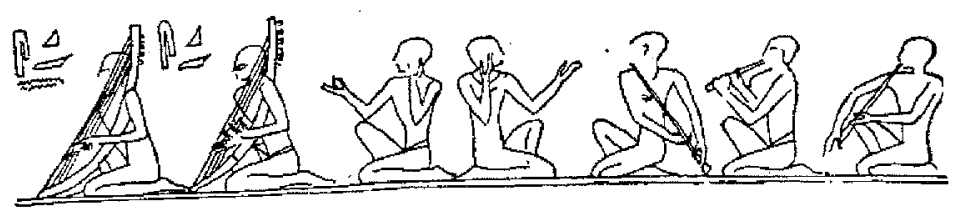

Figura 16. Orquesta del Imperio Antiguo. Tumba de Debhen. 
en los que se practicaba una hendidura en la parte superior, con el fin de obtener una lengüeta simple. Estos tubos tenían una ligera diferencia de afinación entre sí, con lo cual se conseguía un timbre especial en cada uno de ellos. En el ámbito mediterráneo y griego se conocería con el nombre de «doble aulós». La llamada "zumarra», en el Egipto actual, es heredera directa de este tipo de instrumentos.

El oboe y doble oboe, de origen asiático, se fabricaba con cañas muy finas, de unos $30 \mathrm{~cm}$. de longitud, y, por lo general era tocado por mujeres, componentes de las orquestas o grupos musicales de carácter cortesano, que animaban las fiestas durante el Imperio Nuevo. Incluso se han conservado delicados estuches destinados a guardar tan frágiles y delicados instrumentos (fig.17).

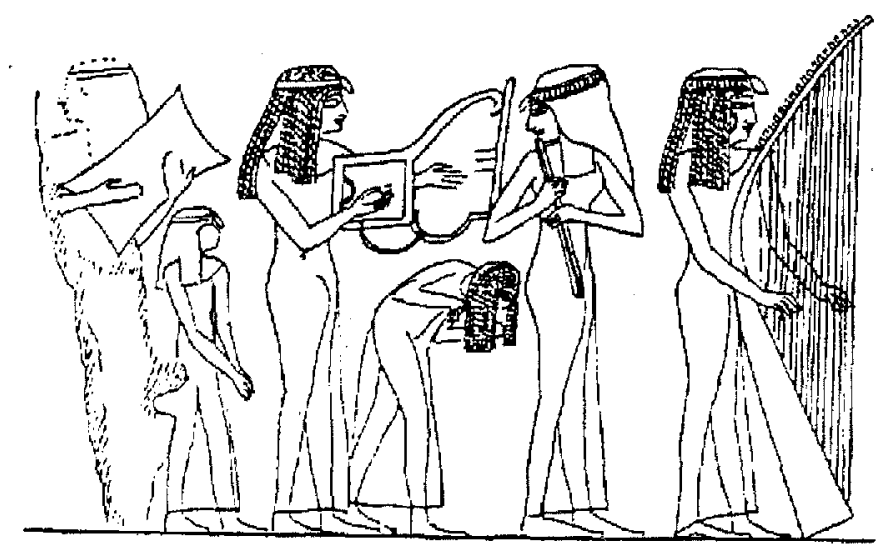

Figura 17. Orquesta del Imperio Nuevo. Tañedoras de arpa, tocadoras de oboe, lira y tambor rectangular. Tumba tebana anónima, $n^{\circ} 129$

En cuanto a la trompeta, puede decirse que su presencia se remonta a tiempos de la $V$ dinastía. Se componía de un tubo cilíndrico de metal, con pabellón y boquilla. Se decía que su inventor había sido el propio Osiris y su uso se limitaba a las ceremonias militares y funerarias. Por lo general, suelen aparecer en parejas, como sucede con las halladas en la tumba de Tutankhamón. De estas dos singulares piezas, una tiene el pabellón de bronce y la otra de plata. En el primero, aparecen grabadas la figura del faraón, junto a las divinas de Ptah, Re-Harakte y Amón-Ra, quien le acerca hasta su nariz el signo del "ankh», para insuflarle la vida eterna. En el segundo, los motivos ornamentales son flores de lotos combinados con 
los cartuchos del nombre del faraón, intercalados entre los sépalos, además de una escena en la que Ptah recibe a Amón-Ra y Re-Harakte. Sin embargo, si se hace caso a Plutarco, quien aseguraba que el sonido de las trompetas egipcias, era semejante al rebuzno de un burro, hay que pensar que, efectivamente, eran muy distintas a las que Verdi hizo sonar en Aida (fig.18).

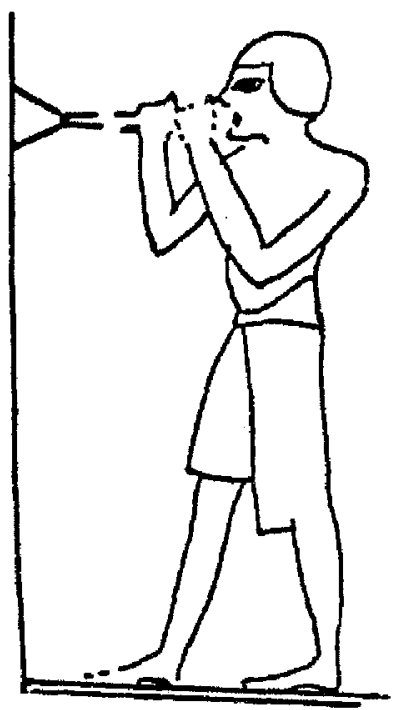

Figura 18. Tocador de trompeta. Tumba de Nebamón. Imperio Nuevo

De la familia de los cordófonos, en Egipto, destacó el arpa («bin.t»; la letra «t», indica su género femenino), usada con profusión ya desde el Imperio Antiguo (IV dinastía, hacia el 2600 a.C), aunque su origen haya que buscarlo en tierras de Mesopotamía, donde ejemplares de una singular belleza de diseño, aparecieron entre las piezas que componían los suntuosos ajuares de las necrópolis reales de Ur I (primera mitad del III milenio a.C). En sánscrito se la conoce con el nombre de "vina», con el cual se alude, asimismo, a diversos instrumentos de cuerda. Flavio Josefo la cita como "tó buní», lo que dió origen al término erróneo de "tebuni» utilizado por los historiadores de la música del siglo XIX (figs. 16 y 19).

Anteriormente, ya se ha dicho, que su genesis debe relacionarse con las vibraciones de las cuerda del arco, capaz de sugerir la manipulación de tales sonidos. A este respecto, conviene recordar que en la antigüedad se 


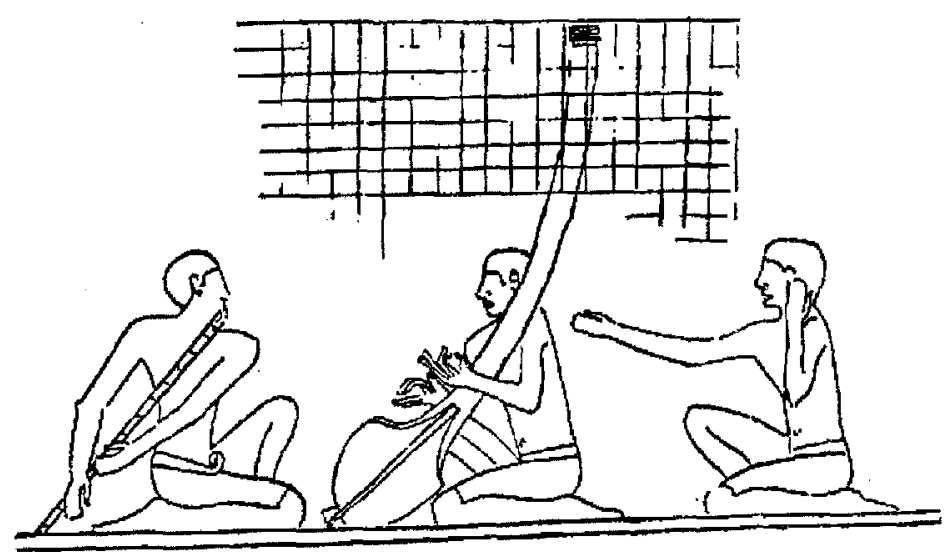

Figura 19. Orquesta del Imperio Medio. Tocador de flauta oblicua, Tañedora de arpa de pala y cantante. Tumba de Ukhotep

solía hablar del "arpa de Eolo", compuesta, al parecer, por una caja sonora, provista de seis u ocho cuerdas afinadas en un mismo tono y en la cual, expuesta a una corriente de aire, se producian unos agradables sonidos.

El arpa, de mayor o menor tamaño, es en realidad un instrumento musical de figura curva o triangular, con cuerdas dispuestas verticalmente y que se tañe con ambas manos. Para tocarla bien se precisa de un excelente oído y de una particular delicadeza. A juzgar por las representaciones de orquestas que hasta nosotros han llegado, puede observarse que, en Egipto, desde tiempos muy remotos, se suele asociar la figura del arpista con la del músico ciego, ya que, dada la especial sensibilidad de los invidentes, debió de fomentarse entre ellos las enseñanzasa musicales. De esta forma se les convertía en seres útiles para desempeñar un oficio en la corte y en los templos. Es probable que la fuente de inspiración de la imagen del Homero ciego, acuñada, con singular efectismo, en época helenística, se encuentre en los prototipos de los arpistas egipcios (fig. 20).

En las representaciones más arcaicas, los arpistas suelen aparecer sentados en el suelo. Las arpas, naviformes o en forma de arco, se apoyaban, a veces, en un soporte en forma de «nudo de Isis». Después se generalizaron las llamadas arpas de «pala o remo», de tamaños muy variables. Solían ser de madera, y el número de cuerdas era variable y estaba en función de su tamaño, llegando incluso a tener diecisiete. Las más grandes eran las «de pie», ya que eran tañidas por los músicos, en dicha postura. Las «de hombro» tenían el aspecto de un salterio y se tocaban 


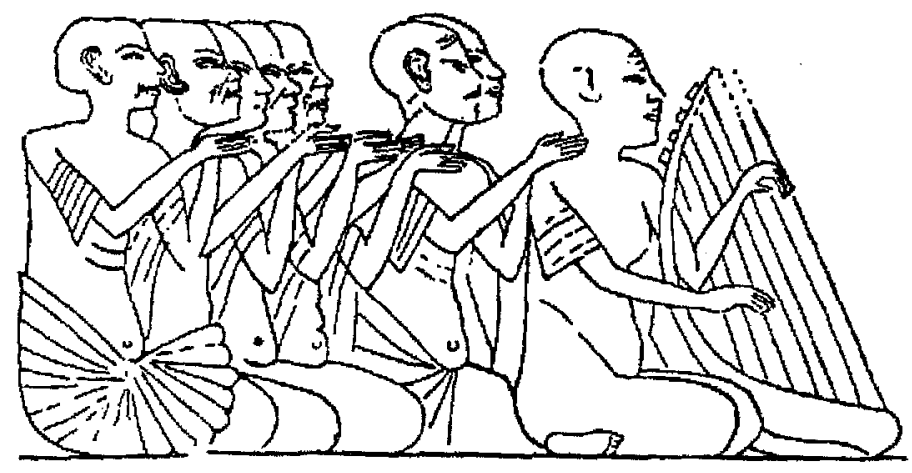

Figura 20. Músicos ciegos. Tumba de Merire I.

apoyadas en la mencionada parte del cuerpo. Tenían entre tres o cinco cuerdas, hechas de tripas o tendones de origen animal y algunas llevaban inscrito en su mástil el nombre de su propietario y una jaculatoria en honor de Amón. También fueron frecuentes las «arpas de cuchara», semejantes en su forma a la "sambuca» siria, algunas de las cuales fueron de gran tamaño, sobre todo en época ramésida (figs. 21 a 24).
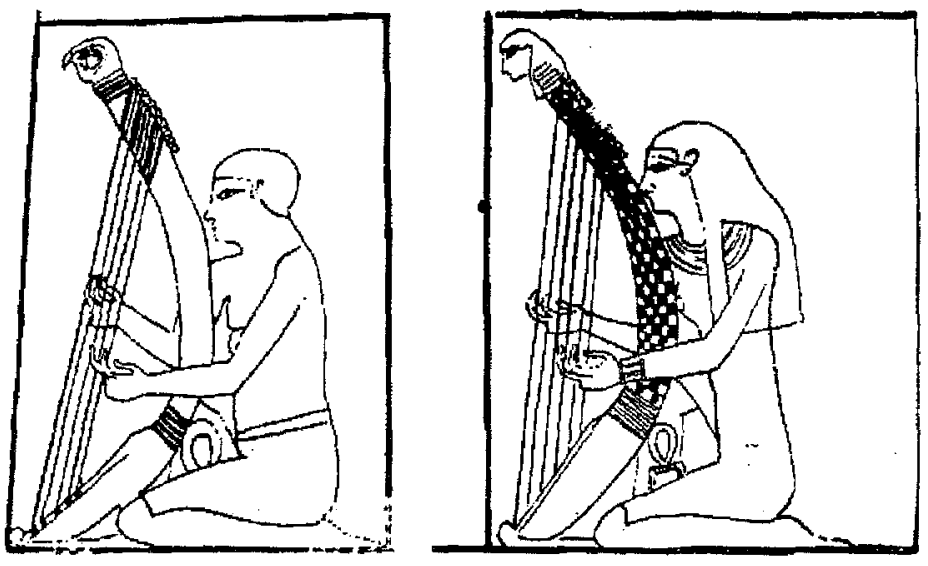

Figura 21. Arpistas de la tumba de Antefoker. Imperio Medio 


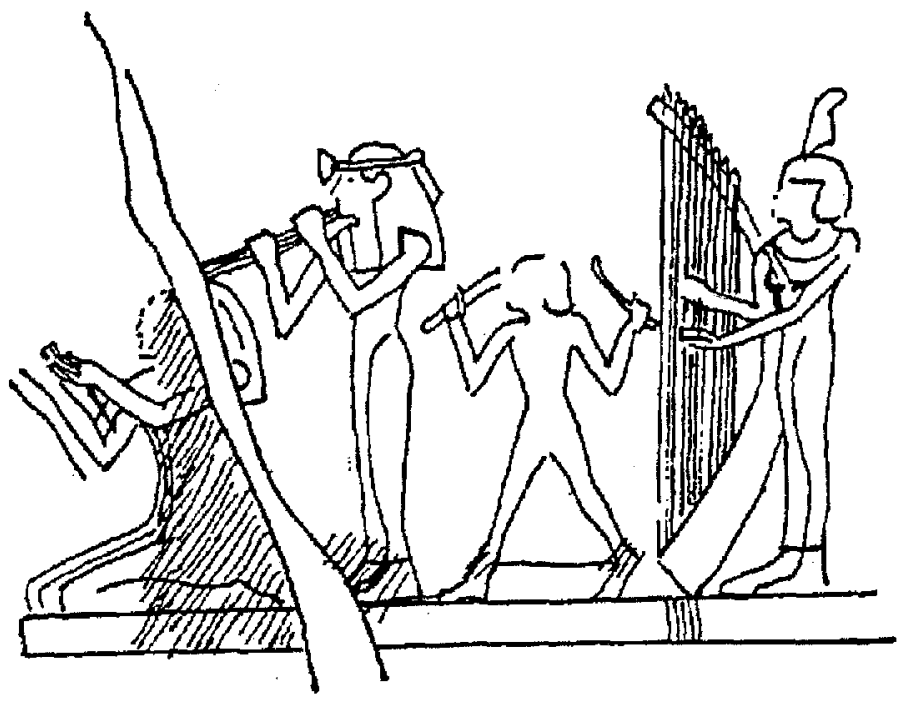

Figura 22. Orquesta femenina. Tañedora de lira de pie, tocadora de crótalo, tocadora de oboe y palmera. Tumba de Paheri

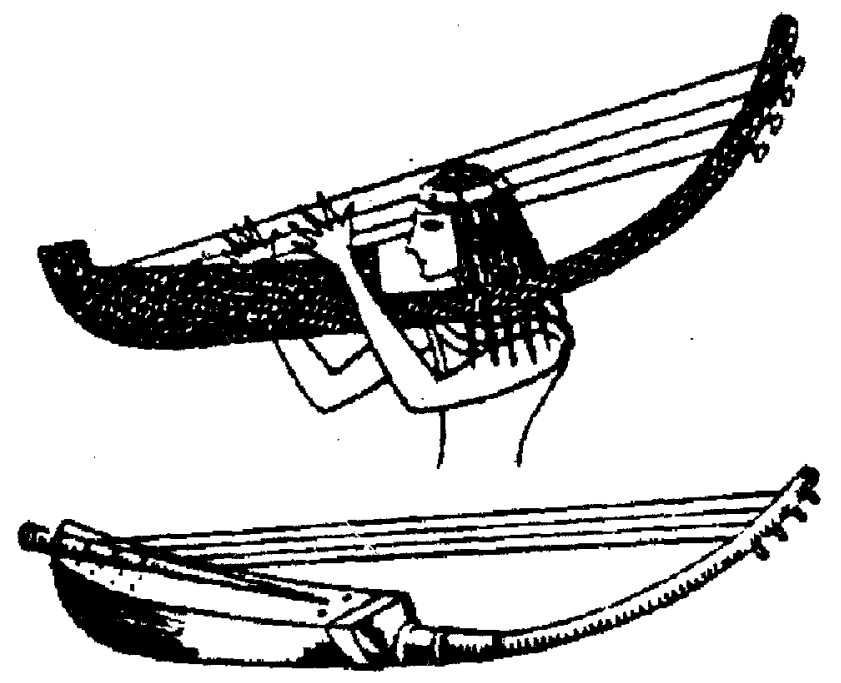

Figura 23. Arpa de hombro o salterio. 

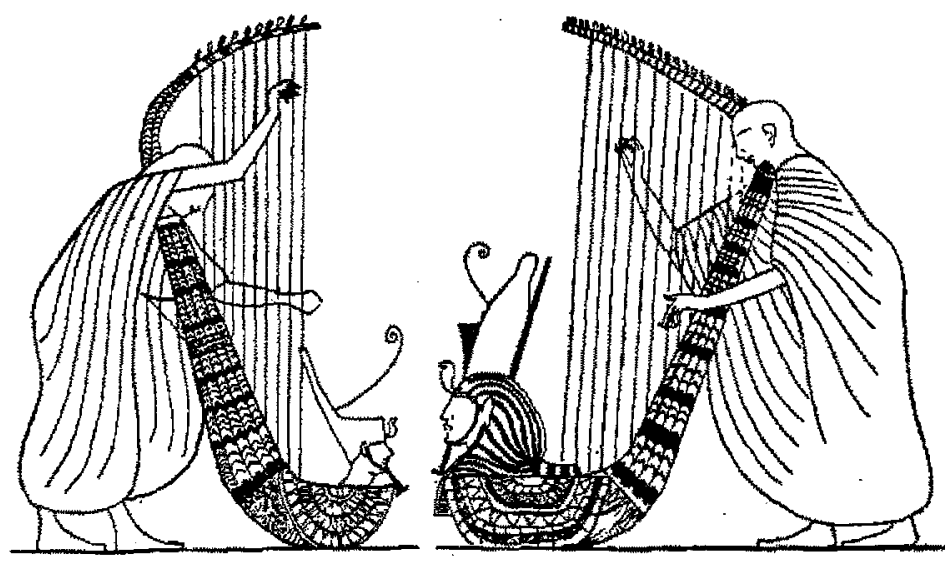

Figura 24. Arpistas de la tumba de Ramsés III (1198-1166 a.c.)

Por otro lado, de origen sirio, al igual que la lira, y de época más tardía, ya que su uso se generalizó en el Imperio Nuevo, es el «arpa angular». La caja de resonancia era de madera recubierta de cuero y, afortunadamente, hasta nosotios han llegado tres magníficos ejemplares conservados en el Museo Metropolitano de Nueva York, en el del Louvre, en Paris, y en el Museo de Berlín (fig.25).

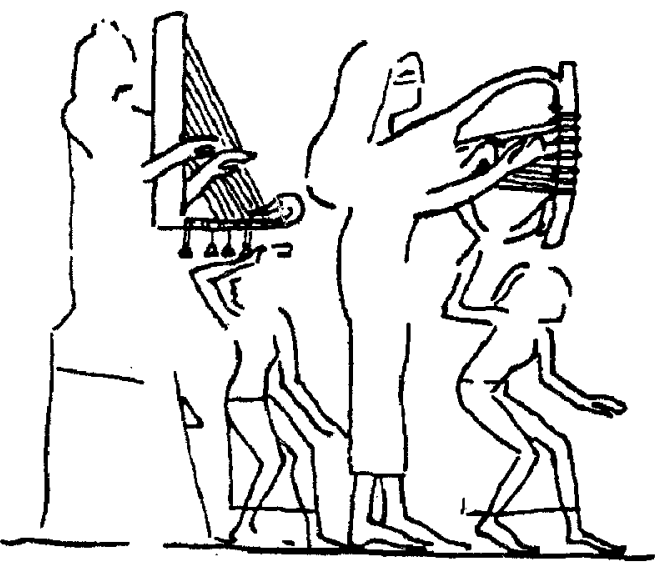

Figura 25. Tañedora de arpa triangular y tañedora de lira de brazos simétricos. Tumba de Nakhtamun. Imperio Nuevo 
El laúd (alud, en árabe) fue otro instrumento de cuerda, originario del Próximo Oriente, que se generalizó a partir de la dinastía XVII, cuando en el trono de los faraones aún se sentaban los hicsos, pueblo de origen asiático de discutida filiación. Se fabricaba de muy diversos tamaños, siendo su caja de resonancia de madera o de concha de tortuga en los ejemplares más pequeños y manejables. Se tañia con plectro y era el instrumento ideal para músicos y músicas solistas que cantaban y bailaban al mismo tiempo. Ecos de antiguo laúd egipcio es el «gunibri» del mundo árabe, llamado «gumbri» en Marruecos y Senegambia (fig. 26).

En cuanto a la lira, también de origen asiático, se generalizó en Egipto a partir del Imperio Medio. Citada con el nombre semita de «k.nn.r» («kinnor», en hebreo; «kinnara», en árabe; «ginera», en copto) aparece en un

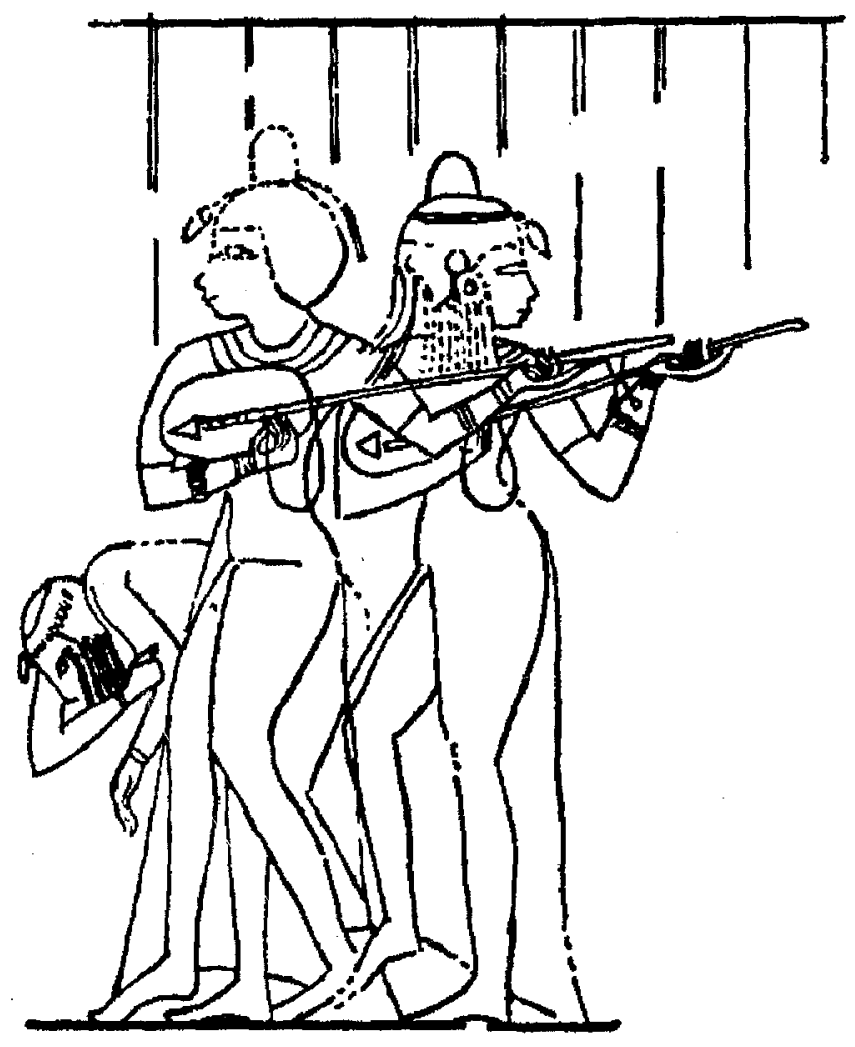

Figura 26. Tañadora de laúd. Tumba de Horemheb (1348-1320 a.C.) 
papiro fechable hacia el 1300 a.C. En el Imperio Nuevo se caracterizó por tener una caja de resonancia de forma cuadrada y poco profunda, dos brazos divergentes y asimétricos y un travesaño oblicuo. Las cuerdas, tañidas con plectro, se aseguraban en un soporte colocado en el frente de la caja. A partir del año 1000 a. C. llegó, asimismo de tierras del Próximo Oriente, la lira pequeña, de brazos simétricos y paralelos y travesaño dispuesto en ángulo recto (figs. 25 y 27 ).

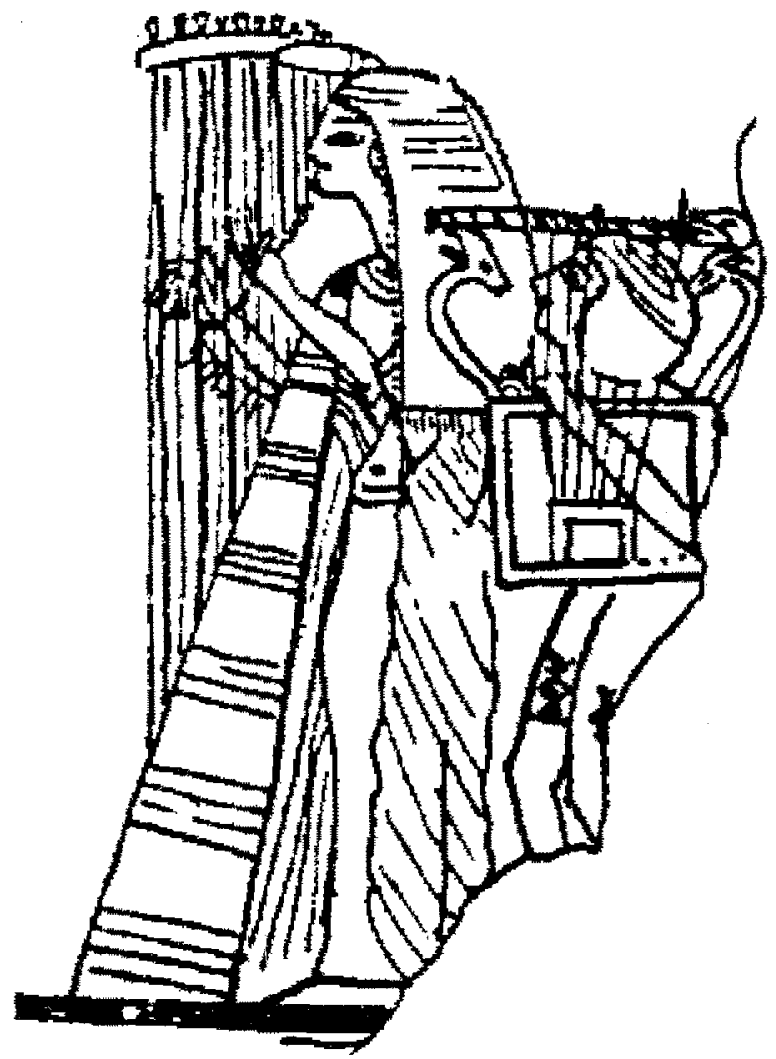

Figura 27. Tañedora de arpa de pie y tañedora de lira de brazos simétricos. Tumba de Paser. Imperio Nuevo

Como ya se ha dicho, lo cierto es que en la evolución de la orquesta y de los componentes de su elenco, la llegada de princesas de origen oriental ( hititas, babilonias, mitanias, etc.) desde el Imperio Nuevo, fue el factor decisivo. El cambio de usos y modas se advierte, con una simple ojeada, a las pinturas que en las tumbas tebanas reproducen escenas de música y 
danza. Escenas que hacen referencia, es bien cierto, al mundo del más allá, pero que reflejan, sin la menor duda, las celebradas en actos civiles y cortesanos de ese "más acá" que con tal fuerza amó el egipcio que su único deseo fue el de disfrutar de él eternamente. Así, de la orquesta oficial del Imperio Antiguo y Medio, compuesta por músicos, exclusivamente, se pasó a la del Imperio Nuevo, formada en su mayoría por jóvenes intrumentistas, cantantes y bailarinas, expertas en el manejo del arpa, laúd, lira, oboe, etc. Ataviadas con vaporosos vestidos plisados y luciendo elegantes pelucas, coronadas por conos de perfume sólido y ceñidas por coronas florales o bellos lotos azules, constituyen una de las galerías de personajes femeninos más atrayentes del antiguo Egipto (fig. 28).

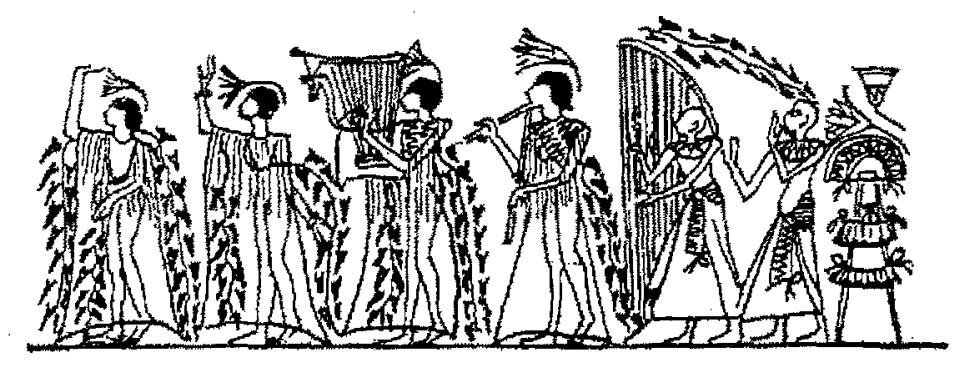

Figura 28. Orquesta del Imperio Nuevo. Epoca de El Amarna (1379-1362 a.c.)

En cuanto a la danza se refiere, hay que decir que las escenas en que se representan a bailarines de ambos sexos son muy numerosas, pero en ellas se observa que las actitudes, pasos y gestos son poco varíados. Probablemente porque, muy pronto, pasaron a convertirse en danzas regidas por el ceremonial de los templos. Por otro lado, se da el hecho curioso de que las bailarinas son, por lo general, como es y ha sido frecuente en este tipo de manifestaciones rítmico-artísticas, muchachas muy jóvenes, de flexible anatomía, que muestran sus cuerpos cubiertos tan sólo por un faldellín corto y ajustado, de suerte que sus senos, poco desarrollados, quedaban al descubierto. Así, hay escenas en las que sus siluetas pueden, incluso, confundirse con la de muchachos, también adolescentes.

Acompañadas por los instrumentos de percusión y relacionadas con el mundo agrario y el de la caza aparecen documentadas las "danzas de palillos o crótalos» y las «danzas del boomerang». En el gran santuario de Heliópolis, animadas por los «cantos de Isis y Neftis», se interpretaban 
las «danzas cosmogónicas» dentro del ritual de carácter funerario vinculado con la muerte y resurrección de Osiris, celebrado en el templo de Isis, y al cual se solían consagrar cinco días. En su transcurso se recitaban poemas, con alternancia de voces masculinas y femeninas. Mediada la ceremonia, un "chantre" o sacerdote, entonaba un canto en honor de Osiris, siendo contestado por los coros de voces masculinas o femeninas que bailaban en corro y con los brazos arqueados sobre las cabezas, recordando, en opinión de algunos tratadísticas, los cuernos de la diosa Hathor, o el arco de la bóveda celeste, según otros. Los pies se movian, en este caso, de forma lenta y acompasada, al tiempo que las filas de los bailarines se cruzaban o giraban. En todas las escenas de música y danza, los jaleadores, casi siempre presentes, marcaban con sus palmeos el ritmo y los cambios de pasos (figs. 29 y 30 ).

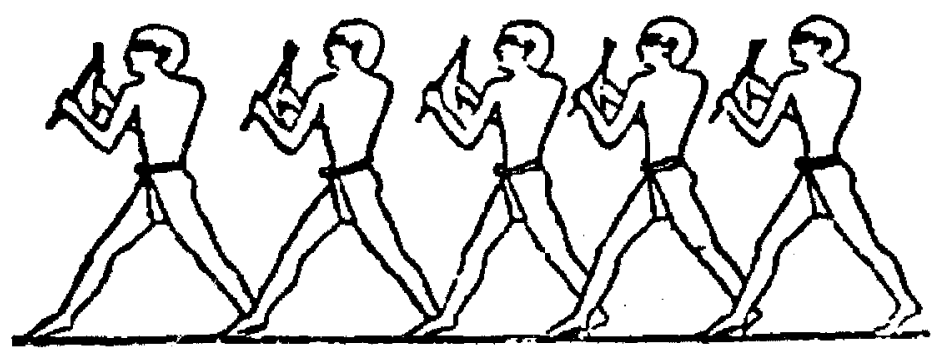

Figura 29. Baile de los segadores con «palillos de entrechoque». Dinastía $V$

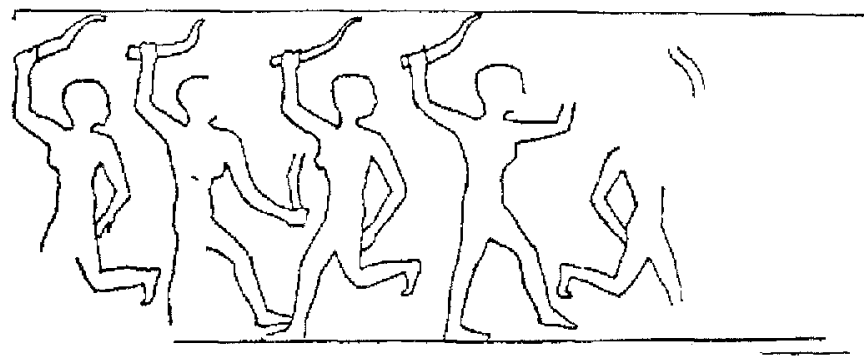

Figura 30. "Danza del boomerang" interpretada por jóvenes bailarinas. Taumba de Khentikaus 
Las representaciones de las «danzas hatóricas» son las más frecuentes y variadas. En un principio fueron de carácter acrobático y festivo, pero, más tarde, se vieron sometidas al rigor de un aprendizaje académico, cuyo principal centro de enseñanza se encontraba en la escuela oficial de música y danza, aneja al templo de Dendera. Aquí, bajo el patrocinio de la dios Hathor e su hijo Ihy, se establecieron las normativas procesionales y ceremoniales, llamadas a tener una larga pervivencia en todo tipo de celebraciones religiosas y funerarias (figs. 4, 12 y 31 ).

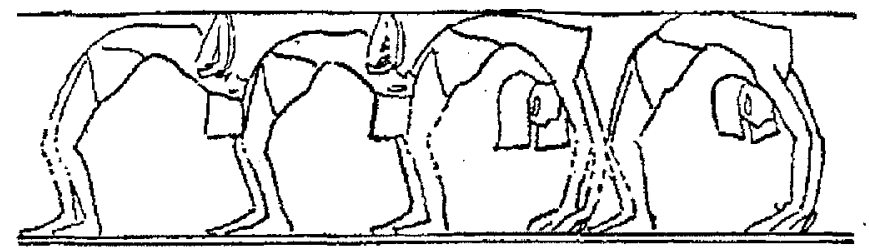

Figura 31. acrobática. Templo de Luxor en Tebas

Por otro lado, todos los grandes templos tuvieron su propia escuela de música, canto y danza, de tal suerte que los profesionales que en ella se formaban, se convertían en personal adscrito al templo. Curiosas escenas recogen el ambiente de estas escuelas, donde maestras rigurosas corregian las posturas y pasos de sus alumnas en las que debían ser duras sesiones de aprendizaje y ensayos (fig. 32).

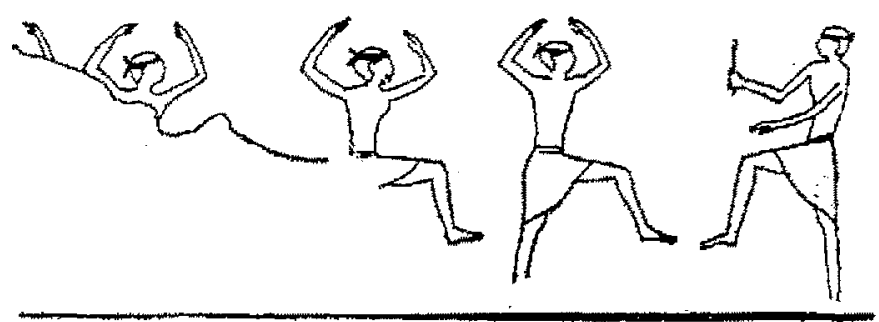

Figura 32. Escuela de danza. Tumba de Ahanakt 
Las danzas con las que se amenizaba el desarrollo de los, actos oficiales de cierta importancia también se conservan ampliamente documentadas, como es en el caso del traslado de estatuas, de la erección de un pilar sa grado(«djed»), o de un obelisco, de la recepción de embajadas procedentes de cortes extranjeras, etc (figs. 33 y 34 ).

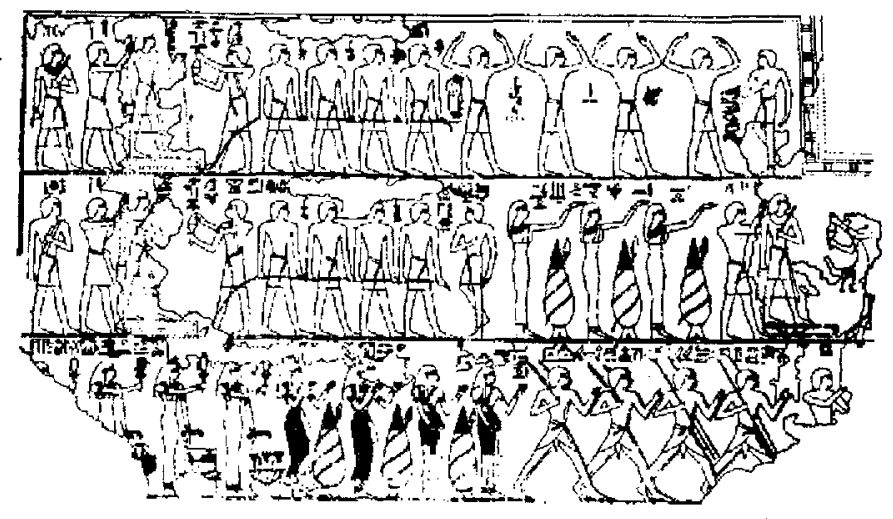

Figura 33. Ceremonias y danzas en el transcurso de la erección del pilar «djed». Tumba de Kheruf

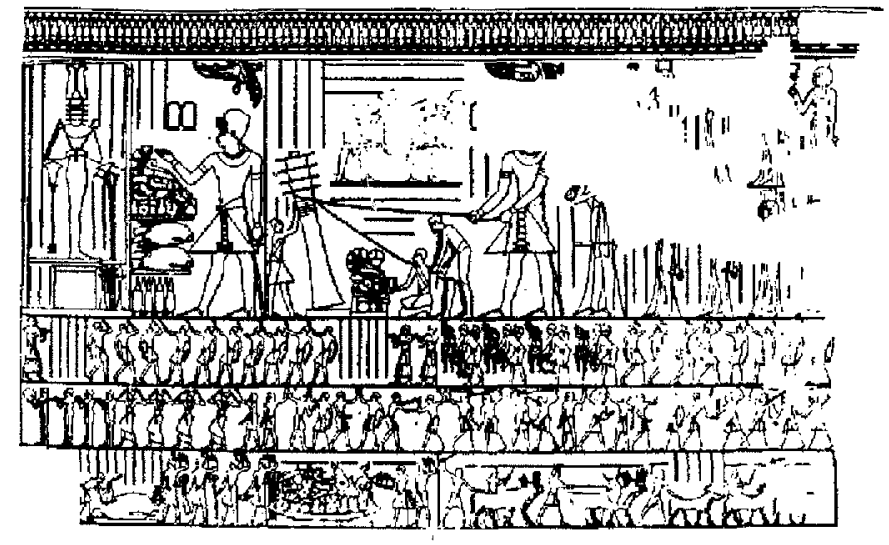

Figura 34. Danzas interpretadas durante el transporte de estatuas de Kenamun 
Curiosamente, en Egipto, no se percibe el eco frecuente de danzas de guerra, mientras que se prodigan, hasta la saciedad, las escenas bélicas y de exaltación de las victorias del faraón frente a sus enemigos. Tal vez el hecho de que, a partir del año 3000 a.C., la unificación del pais hiciera del Estado un único e indiscutible instrumento de poder, hizo innecesario la exaltación patriótica por medio de la expresión enardecedora, tan eficaz en muchos pueblos y culturas.

Son célebres las maquetas, fechables en el Imperio Medio, en las que aparecen representados los ejércitos de infantería egipcios con todo realismo. En realidad, sorprenden por la indefensa desnudez de lo tostados cuerpos de los soldados, que sin más impedimenta que sus faldellines cortos, sus arcos y flechas, a veces, y otras espadas y escudos, pisan la oscura tierra egipcia con sus pies, también desnudos, sin el menor indicio de un acompañamiento de música de trompetas. Sin embargo, no faltan algunas representaciones de «danzas guerreras», tales como las que decoran algunos paneles del templo de Luxor, en Tebas.

Impresionantes son, en cambio, las escenas que en los cortejos funerarios evocan las ruidosas manifestaciones de duelo por parte de las plañideras, que en compactos grupos, muestran sus desesperación oficializada ante la muerte del faraón o cortesano de alcurnia. El llanto desgarrador 0 , incluso, un ulular semejante al que emiten hoy las mujeres del norte de África, en casos de desgracia o duelo, debía de estremecer la tierra a lo largo de todo el recorrido de la pompa mortuaria, tanto a lo largo del río, como por los caminos conducentes a su última morada.

De las danzas cortesanas y de haren, ya hemos dicho, que existe un nutrido repertorio en las pinturas de las tumbas tebanas. En ellas se dejó constancia cumplida del dulce vivir en el interior de los gineceos, donde las damas ilustres dedicaban sus ocios a su cuidado y embellecimiento personal, mientras eran entretenidas con los cantos y danzas de sus esclavas, expertas en el arte de la interpretación musical. Dentro del Imperio Nuevo, capítulo especial merecen las manifestaciones de El Amarna, ya que en la corte de Akenatón y Nefertiti tuvieron cabida las más refinadas expresiones de todas las artes.

Tampoco faltaron las danzas mágicas y propiciatorias, de carácter popular, relacionadas, en su mayoría, con ascestrales rituales de fecundidad y, en consecuencia, asociadas con el renacer agrario. De entre ellas, cabe destacar la «danza de Bes», divinidad deforme, con el aspecto de un enano barbudo, de piernas torcidas, al que se le consideraba genio de la fecundidad y protector de la mujer y de la infancia. Se suponía que se divertía bailando y cantando aires populares y haciendo muecas de burla 
con las que hacía reir a grandes y pequeños. Tal vez, la desgracia que todavía arrastran muchos enanos, que se ven obligados a ganarse la vida en espectáculos grotescos o crueles charlotadas, no sea más que una herencia del cometido del cometido del que se ecargaba Bes, el dios enano y contrahecho.

Por último estaban las «danzas de brujería o de hechizo», de las cuales tampoco faltan los testimonios gráficos y literarios. En general se las consideraba danzas de carácter extranjero, por lo que solía llamársela «nubias» o «libias». Esto indica que, en alguna forma, por sus extravagancias y excesos, se las consideraba fuera de las normas establecidas para las propiamente egipcias. De este tipo de danzas, destacaba la llamada de "los brujos", tal vez por su carácter de encantamiento o de magia negra (figs. 35,36 y 37 ).

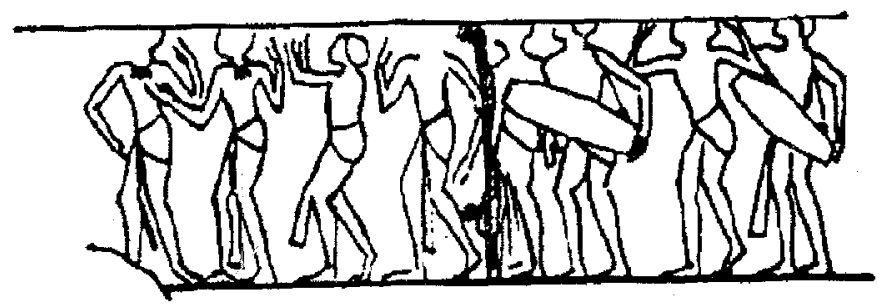

Figura 35. Danza nubia. Templo de Ermant

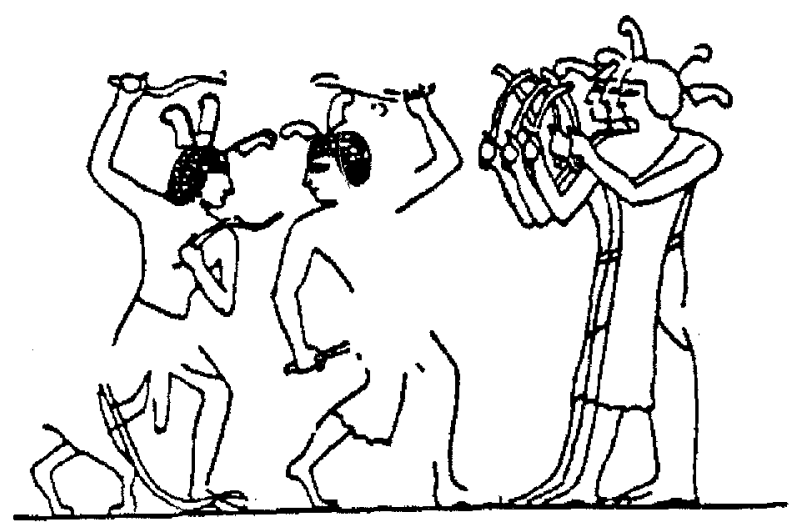

Figura 36. Danza libia. Templo de Deir el-Bahari 


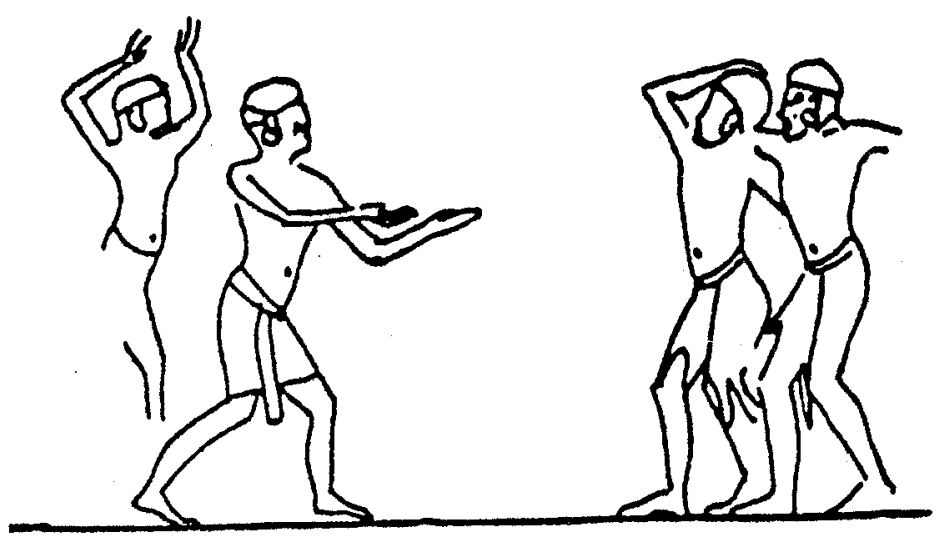

Figura 37. Danza de los brujos. Capilla de Bebel Silsileh

A partir de la época ptolemaíca, la música egipcia recibió los influjos de la griega, iniciándose un nuevo y singular capítulo, dentro del cual se pueden distinguir varias modalidades. Sin embargo dos fueron los focos más importantes, a partir de entonces y como ya había sucedido en épocas de crisis anteriores: el del Alto Egipto y el del Bajo Egipto. En el primero se concentraron las corrientes tradicionales. En el segundo, en el Delta, abierto al Mediterráneo, se produjo un sincretismo receptivo y permeable a toda suerte de innovaciones dinámicas, llamadas a tener una larga proyección en su futuro.

\section{BIBLIOGRAFÍA.}

Castelo, R., y López, M.J.: Instrumentos musicales egipcios. Bol. Asoc. Esp. Orient., Año XXV. Madrid, 1989.

HiCKMAN, H.: Musicologie pharaonique. Études sur l'evolution de l'art musical dans l'Egypte ancienne. El Cairo, 1956.

MANNICHE, L.: Ancient Egyptian Musical Instruments. Müncher Egyptologische Studien, nº 34, Munich, 1975.

Robertson A., y Stevens, D.: Historia General de la Música, tomo I, Madrid, 1972, p.22 y ss.

Sachs, C.: Historia Universal de los instrumentos Musicales. Buenos Aires, 1947, p. 83 y ss.

VANDIER, J.: "La musique, la danse et les jeux», en Manuel d'Archéologie egyptienne, Paris, 1964 , vol IV, p. 364 y ss. 